\title{
First record of Voyria caerulea Aubl. (Gentianaceae), a mycoheterotrophic plant, in Maranhão state, northeastern Brazil
}

\author{
Alessandro Wagner Coelho Ferreira ${ }^{1}$, Maria Fernanda Calió ${ }^{2}$, Wagner Ribeiro da Silva Junior ${ }^{1}$, \\ Maycon Jordan Costa da Silva ${ }^{1}$, Miguel Sena de Oliveira ${ }^{3}$, Eduardo Oliveira Silva ${ }^{4}$, Elidio \\ Armando Exposto Guarçoni ${ }^{5}$, Andressa Ketilly Cabral de Carvalho ${ }^{1}$, Nivaldo de Figueiredo ${ }^{1}$
}

1 Federal University of Maranhão, Department of Biology, University City Dom Delgado, Av. dos Portugueses, 1966, Bacanga, CEP 65080-805, São Luís, MA, Brazil. 2 State University of Campinas, Department of Plant Biology, Rua Monteiro Lobato, 255, CEP 13083-862, Campinas, SP, Brazil. 3 State University of Maranhão, Department of Chemistry and Biology, Praça Duque de Caxias, s/n, Morro do Alecrim, CEP 65604090, Caxias, MA, Brazil. 4 Federal University of Maranhão, Coordination of Natural Sciences, Codó Campus, Av. Dr. José Anselmo, 2008, São Benedito, CEP 65400-000, Codó, MA, Brazil. 5 Federal University of Maranhão, Coordination of Natural Sciences Biology, Bacabal Campus, Av. Governador João Alberto, s/n, Bambu, CEP 65700-000, Bacabal, MA, Brazil.

Corresponding author. Maycon Jordan Costa da Silva: mayconjordan40@gmail.com

\begin{abstract}
We report the first record of Voyria caerulea from the state of Maranhão, northeastern Brazil. A fertile specimen was collected in a gallery forest during the rainy season, within the boundaries of the municipality of São Raimundo das Mangabeiras. This find contributes to the knowledge on the micoheterotrophic flora of Maranhão and expands the geographic distribution of this species in Brazil. We also present a taxonomic description, illustrations, an occurrence map of the newly found population, and an identification key for all the species of Voyria that occur in Maranhão.
\end{abstract}

Key words

Brazilian flora, mycoheterophy, new occurrence.

Academic editor: Juliana de Paula-Souza | Received 22 May 2018 | Accepted 27 September 2018 | Published 5 October 2018

Citation: Ferreira AWC, Calió MF, Silva Junior WR, Silva MJC, Oliveira MS, Silva EO, Guarçoni EAE, Carvalho AKC, Figueiredo N (2018) First record of Voyria caerulea Aubl. (Gentianaceae), a mycoheterotrophic plant, in Maranhão state, northeastern Brazil. Check List 14 (5): $833-837$. https://doi.org/10.15560/14.5.833

\section{Introduction}

Gentianaceae Juss. is composed by 99 genera and approximately 1,700 species that are widely distributed across the globe, except in Antarctica. In Brazil, the family is currently represented by approximately 31 genera and 122 species (BFG 2015). Although most plants in the family are autotrophic, mycoheterotrophy has been reported for 30 species, 18 of which belong to Voyria Aubl. (Maas and
Ruyters 1986, Struwe et al. 2002, Gentian Research Network 2011, Merckx et al. 2013a, b). Voyria species are achlorophyllous, fully mycoheterotrophic plants; that is, they have lost the ability to perform photosynthesis and completely depend on symbiotic associations with fungi to obtain carbon during their entire life cycle (Merckx et al. 2013a, b). They are small, delicate herbs with yellowish, orange, reddish, or whitish stems and with leaves reduced in size (Maas and Ruyters 1986, Merckx et al. 


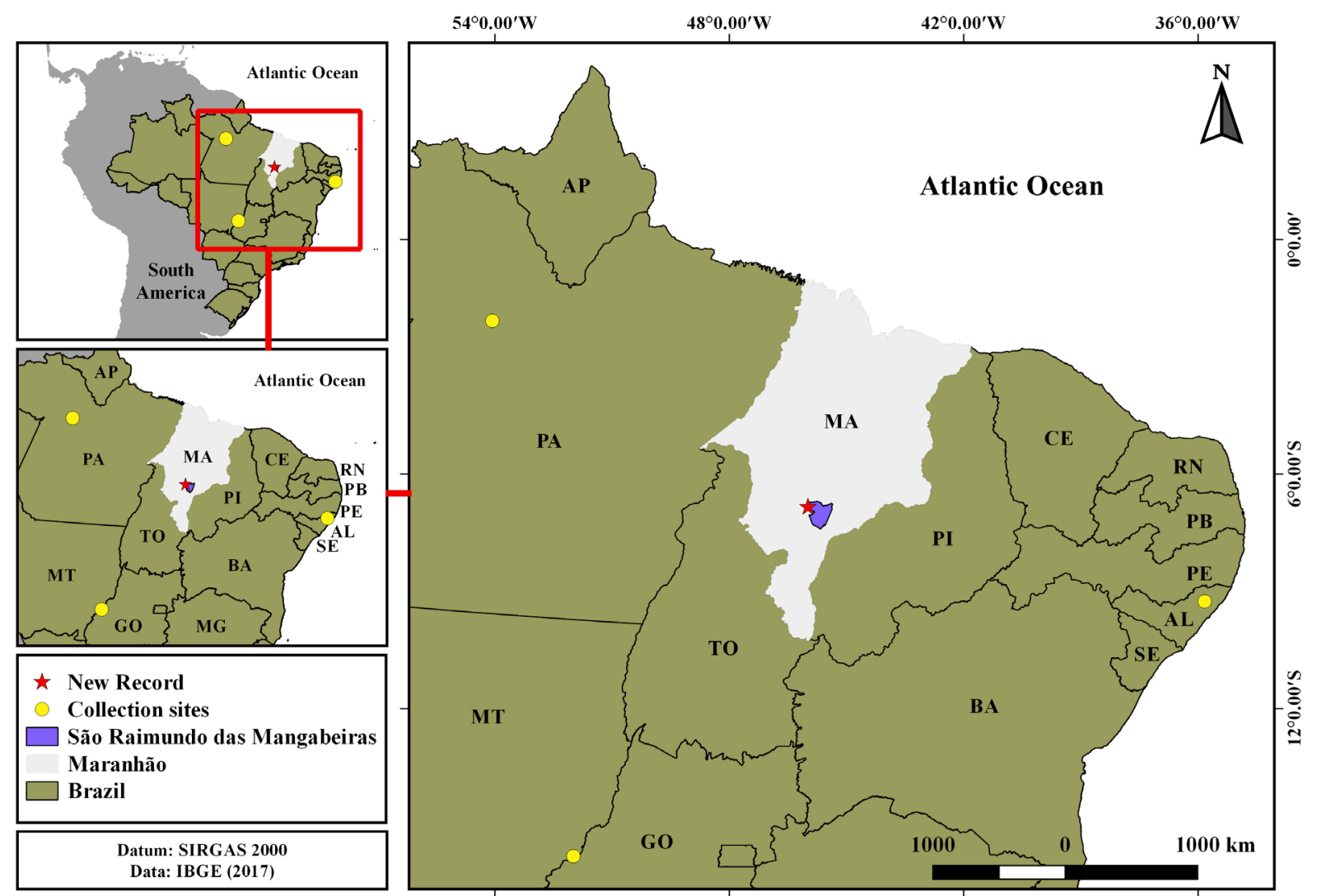

Figure 1. Collection site of Voyria caerulea Aubl. in Maranhão state, northeastern Brazil. $\star=$ new record. $\bigcirc=$ previous collections of Voyria caerulea closer to the new record.

2010, 2013a, b). They are small in size, typically are visible only when their brightly colored (yellowish, blue, or whitish) flowers bloom, and rarely form large populations; for these reasons they are difficult to observe in the field and are not frequent in herbaria (Struwe et al. 2002, Merckx et al. 2010, 2013a, b, Courty et al. 2011, Gentian Research Network 2011).

A specimen identified as Voyria caerulea Aubl. was collected during fieldwork in Maranhão state, in which until recently, only 4 species of Voyria had been reported: $V$. aurantiaca Splitg., V. flavescens Griseb., V. spruceana Benth., and $V$. tenella Guild. ex. Hook. (Voyria in Brazilian Flora 2018, Koch and Araújo-Silva 2014). We report the occurrence of this rare species from Maranhão, Brazil, and present an identification key to the species of Voyria known to occur in in this state.

\section{Methods}

We collected Voyria caerulea Aubl. during field expeditions in February 2017 within the boundaries of the municipality of São Raimundo das Mangabeiras, central region of Maranhão state, Brazil. Plants were found on the banks of the Gameleira Creek, a tributary of the Itapecuru River, in the Itapecuru basin, in a gallery forest adjacent to an area of Cerrado (Brazilian savanna) (Fig. 1). This area is threatened by fires caused by agricultural activities during the dry season from April to
September (Silva-Júnior et al. 2018)

Plants were photographed with a digital camera and a Tecnal ${ }^{\circledR}$ ME-SZ stereoscopic microscope coupled to a Carl Zeiss ${ }^{\circledR}$, AxioCam ERc5s digital camera, and the geographic coordinates of the site were obtained using a Garmin eTrex ${ }^{\circledR} 30 x$ GPS receiver.

Collected specimens were herborized following the Technical Manual of the Brazilian Vegetation (IBGE 2012). To avoid a drastic reduction of the population, only 2 out of the 3 inflorescences observed in the field were collected. The exsiccata was incorporated into the herbarium MAR, located in the Department of Biology of the Federal University of Maranhão, São Luís, Maranhão, Brazil (acronym according to Thiers 2018). Specific literature was used to identify the specimens (Maas and Ruyters 1986, Franke 2002, Maas and Maas 2005, Melo et al. 2010, Gentian Research Network 2011, Melo and Alves 2013), and comparisons with specimens identified by experts at CEPEC, HUEFS, HURB, INPA, JPB, MO, NY, and P (acronyms according to Thiers 2018). The geographic distribution of this species is from the online databases Brazilian Flora (2018), Tropicos (2018) and SpeciesLink (2018). The map was created in QGIS v. 2.14 Essen 4 (QGIS Development Team), using SIRGAS 2000. Figures of specimens were edited using Photoshop ${ }^{\circledR}$ CS5 v. 12.0 (Adobe ${ }^{\circledR}$ Systems) were used to map and illustrate this species, respectively. 


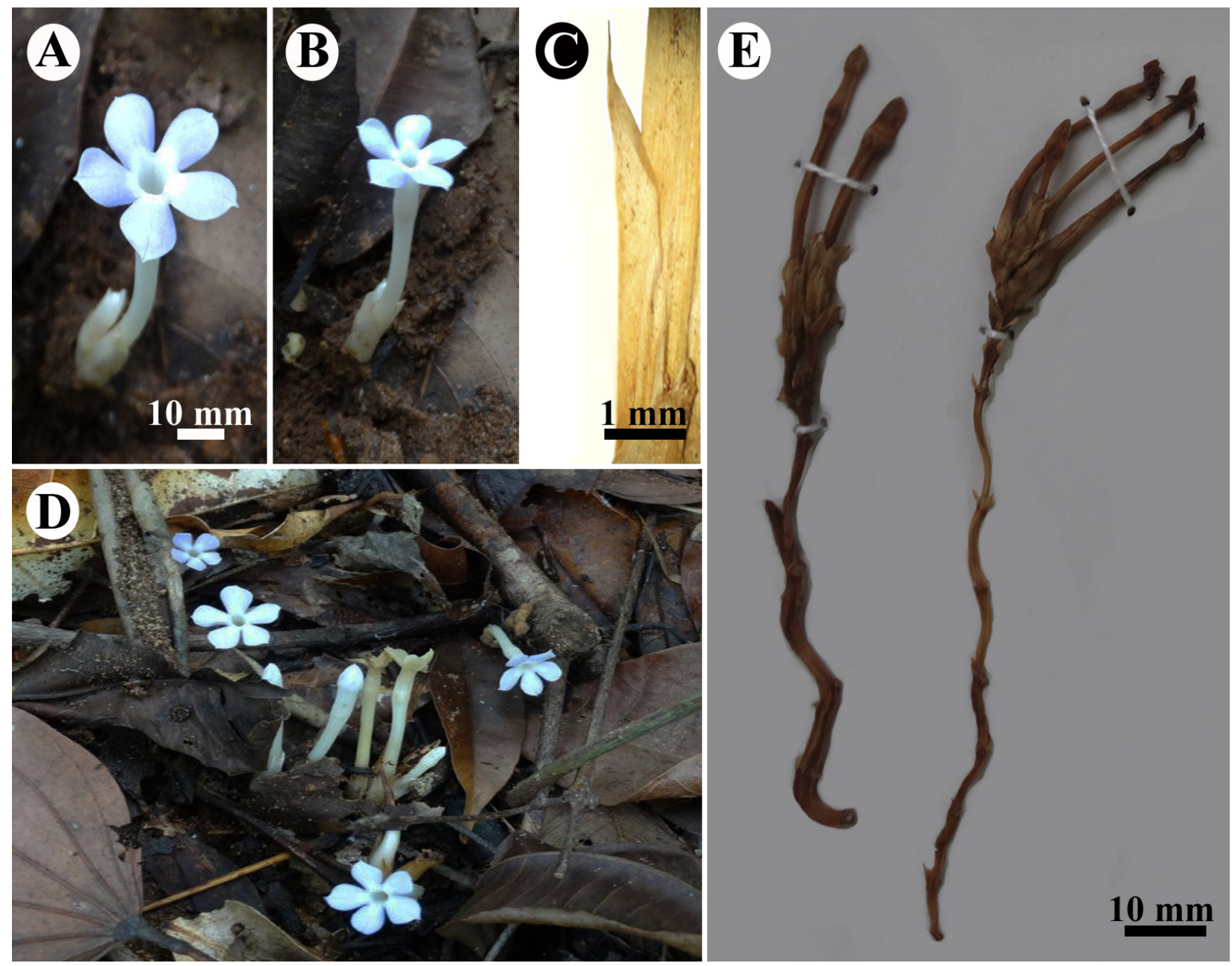

Figure 2. Voyria caerulea Aubl. (A.W.C. Ferreira et al. 251, MAR 9284). A. Flower in frontal view. B. Flower in lateral view. C. Detail of a leaf from a dried herbarium specimen. D. Flowering plants in their habitat. E. Detail of a flowering plant in a dried herbarium specimen.

\section{Results}

\section{Identification key to the species of Voyria Maranhão} state, Brazil

\section{Stem branched}

2. Flowers solitary V. spruceana

$2^{\prime}$. Flowers aggregated in inflorescences

3. Corolla yellow, $15-20 \mathrm{~mm}$ long, lobes elliptic to lanceolate, apical portion rounded to acute V. aurantiaca

3'. Corolla lilac or white, $30-40 \mathrm{~mm}$ long, lobes obovate, apical portion acute ....... V. caerulea

$1^{\prime}$. Stem unbranched

4. Corolla blue or white, salverform, lobes lanceolate, apex slightly acute, roots in star-like clumps .. V. tenella

4'. Corolla yellow, hypocrateriform, lobes elliptic, apex acute, roots short and unbranched

V. flavescens

Voyria caerulea Aubl., Hist. Pl. Guiane, 1: 211, 1775. Figure 2A-E

Type: Aublet s.n. (Holotype): P barcode P00778104 [photo!].
Description. Mycoheterotrophic herb, 70-120 mm tall, 2-3 mm wide. Stem cylindrical, white, branched. Leaves 2-3 $\times 1-2 \mathrm{~mm}$, whitish, opposite, lanceolate, apex acute, connate at base, sessile. Bracts 5-6 $\times 2-3 \mathrm{~mm}$, lanceolate, apex acute. Inflorescence terminal, branched, flowers $2-5$. Flowers erect, pentamerous, stamens inserted in the corolla tube. Calyx 10-12 × 3-4 mm, white, gamosepalous, tubular, infundibuliform, lobes long-lanceolate, 1-2 $\times 1 \mathrm{~mm}$. Corolla $30-40 \times 2-3 \mathrm{~mm}$, lobes obovate, apex acute, gamopetalous, lilac, hypocrateriform. Ovary superior, 5-6 $\times 2 \mathrm{~mm}$, elliptical. Fruits and seeds not observed.

New record. Brazil. Maranhão: São Raimundo das Mangabeiras, Riacho da Gameleira, $\left(06^{\circ} 50.98^{\prime}\right.$ S, $045^{\circ} 59.28^{\prime}$ W), 17.II.17, fl., A.W.C. Ferreira et al. 251 (MAR 9284).

Additional material examined. Brazil. Alagoas: Serra de Jintituba, Flexeiras, $\left[09^{\circ} 15.40^{\prime} \mathrm{S}, 035^{\circ} 49^{\prime} \mathrm{W}\right], 14 . X .2015$, fl., L. Nusbaumer et al. 4611 JPB [photo!] 0061306. Amazonas: Rebio Uatumã, trilha da Suçuarana, Presidente Figueiredo [01 $11^{\circ} 0^{\prime}$ S, $059^{\circ} 15^{\prime}$ W], 25.VII.2007, fl., Ribeiro 2831 (INPA [photo!] 242664). Bahia: road CIA, Salvador, [12 $2^{\circ} 1^{\prime}$ S, $038^{\circ} 22^{\prime}$ W], 25.VII.2004, fl., Carvalho-Sobrinho 257 (HUEFS [photo!] 84665). Mato Grosso: $30 \mathrm{~km}$ (straight line) ENE of Barra do Garças, [15 $\left.46.78^{\prime} \mathrm{S}, 051^{\circ} 59.48^{\prime} \mathrm{W}\right]$, 05.V.1973, fl., W.R. 
Anderson et al. 9783 NY [photo!] 970492. Pará, Lageira, [0205' S, 051 $59.48^{\prime}$ W], 18.VII.1981, fl., J.J. Strudwick et al. $3113 \mathrm{MO}$ [photo!] 2789724. Rio Grande do Norte: BR 101, right entrance after the RN/PB state border, ca $1.5 \mathrm{~km}$ after tax office; vicinal among sugarcane crops. $7.5 \mathrm{~km}$ from the entrance, Canguaretama, [06 $31^{\prime} \mathrm{S}$, $035^{\circ} 10.07^{\prime} \mathrm{W}$ ], 02.VIII.2014, Roque et al. 1563 HURB [photo!] 16911. Sergipe: road Crasto to Santa Luzia do

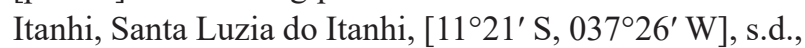
Carvalho 4325 CEPEC [photo!] 59478.

\section{Discussion}

Voyria caerulea occurs in Guyana, French Guiana, Suriname, Venezuela, and Brazil where it is found in areas of the Amazon Forest, Cerrado, and Atlantic Forest, in the states of Amazonas, Pará, Paraíba, Pernambuco, Sergipe, Bahia, and Mato Grosso (Maas and Ruyters 1986, Gentian Research Network 2011, Tropicos 2018, Brazilian Flora 2018). According to the information available in Specieslink (2018), the three sites with previous records of $V$. caerulea closest to this new record in the Maranhão state (Fig. 1) are: 1-) Jintituba Serra, municipality of Flexeiras, Alagoas state, northeastern Brazil, located 1,096 km of distance; 2-) Barra dos Garças, Mato Grosso state, Midwestern Brazil, located at 1,181 km of distance and 3-) Lageira, Pará state, northern Brazil, located 1,038 $\mathrm{km}$ of distance. The loss of habitats caused by fire and deforestation caused by agriculture activities near the new occurrence of $V$. caerulea suggests that this species, as many others inhabiting the Cerrado, may be threatened. In fact, fire and deforestation are associated with the loss of biodiversity in the Cerrado (Abreu et al. 2017).

Our observations in the field point to a the low population density of $V$. caerulea: only 1 individual was found after we walked approximatetly $500 \mathrm{~m}$ along the banks of the creek associated with the studied gallery forest. This is confirmed by the pollination study carried out by Hentrich et al. (2013) in French Guiana where they recorded only 17 individuals of $V$. caerulea along about $20 \mathrm{~km}$ of trails. Hentrich et al. (2013) also reported that $V$. caerulea was visited only once by a butterfly in 6 days of field observations and that its seeds are dispersed concentrically and/or by rodents. Thus, it is a rarely observed, pollinated and collected species, making our new record important.

The rarity of $V$. caerulea at the new site agrees with what is known for this species and others belonging to genus Voyria. In the field, they are clustered in small populations with only a few individuals (Maas and Ruyters 1986, Struwe et al. 2002). Mycoheterotrophic plants, such as V. caerulea, are not very visible and rare, and therefore, the distributions of such plants may be underestimated. Voyria caerulea may also occur in states neighboring Maranhão, where its is still unreported, and additional efforts to document mycoheterotrophic species, such as $V$. caerulea, are needed.

\section{Acknowledgements}

We thank the Federal University of Maranhão, Codó Campus, for providing transportation in the field; the Laboratory of Orchid Studies and the Maranhão herbarium of Federal University of Maranhão, Dom Delgado Campus, for the assistance with fieldwork, image capture, and specimen herborization, FAPEMA for funding (Edital Universal 0430/2015, 009033/2015), and the comments of the reviewers who made it possible to publish this paper.

\section{Authors' Contributions}

WRSJ and AWCF collected and photographed the plant. MJCS, MSO, and AWCF wrote the text. AWCF and MFC identified the specimen. MJCS, WRJS, AKCC, and MSO revised herbarium collections. AWCF, EOS, WRSJ, NF, EAEG, and MFC revised the text.

\section{References}

Abreu, RCR, Hoffmann, WA, Vasconcelos, HL, PILON, NA, Rossatto, DR, Durigan, G (2017) The biodiversity cost of carbon sequestration in tropical savanna. Science Advances 3 (8): el70284. http:// doi.org/10.1126/sciadv. 1701284

Aublet, MF (1775) Histoire des plantes de la Guiane françoise. Vol. 1. P.-F. Disdot, London/Paris, 621 pp.

BFG (The Brazil Flora Group) (2015) Growing knowledge: an overview of seed plant diversity in Brazil. Rodriguésia 66 (4): 1085 1113. https://doi.org/10.1590/2175-7860201566411

Brazilian Flora 2020 (2018) Jardim Botânico do Rio de Janeiro. http:// floradobrasil.jbrj.gov.br/reflora/floradobrasil/FB7792. Accessed on: 2018-3-2

Courty PE, Walder F, Boller T, Ineichen K, Wiemken A, Rousteau A, Selosse MA (2011) Carbon and Nitrogen metabolism in mycorrhizal networks and mycoheterotrophic plants of tropical forests: A stable isotope analysis. Plant Physiology 156: 952-961. https://doi. org/10.1104/pp.111.177618

Franke T (2002) The myco-heterotrophic Voyria flavescens (Gentianaceae) and its associated fungus. Mycological Progress 1: 367-376. https://doi.org/10.1007/s11557-006-0033-8

Gentian Research Network (2011) Gentian Research Network website. http://gentian.rutgers.edu/index.htm. Accessed on: 2018-3-2.

IBGE (2012). Manual técnico da vegetação brasileira: sistema fitogeográfico, inventário das formações florestais e campestres, técnicas e manejo de coleções botânicas, procedimentos para mapeamentos. IBGE, Diretoria de Geociências, Rio de Janeiro, 271 pp.

Koch AK, Araújo-Silva LE (2014) Primeiro registro de Voyria tenella Guild. ex. Hook. (Gentianaceae) para o estado do Maranhão, Brasil. Biota Amazônica 4: 132-134. https://doi.org/10.18561/21795746/biotaamazonia.v4n3p132-134

Leake JR (1994) The biology of myco-heterotrophic ("saprophytic") plants. New Phytologist 122: 171-216. https://doi.org/10.1111/j. 1469-8137.1994.tb04272.x

Maas H, Maas PJN (2005) Flora da Reserva Ducke, Amazonas, Brasil: Gentianaceae. Rodriguésia 56 (86): 169-173.

Maas PJM, Ruyters P (1986) Voyria and Voyriella (Saprophytic Gentianaceae). Flora Neotropica 41: 1-93.

Melo A, Alves M (2013) Sinopse das ervas aclorofiladas ocorrentes no norte da Floresta Atlântica, Brasil. Revista Brasileira de Biociências 11 (1): 29-38.

Melo A, Alves-Araújo A, Alves M (2010) Burmanniaceae e Gentianaceae da Usina São José, Igarassu, Pernambuco. Rodriguésia 61 (3): 431-440. 
Merckx VSFT (2013) Mycoheterotrophy: an introduction. In: Merckx, VSFT (Ed.) Mycoheterotrophy: The Biology of Plants Living on Fungi. Springer-Verlag, New York, 1-17.

Merckx VSFT, Freudenstein JV, Kissling J, Christenhusz MJM, Stotler RE, Crandall-Stotler B, Wickett N, Rudall PJ, Maas-van de KW, Maas PJM (2013a) Taxonomy and classification. In: Merckx, VSFT (Ed.) Mycoheterotrophy: the Biology of Plants Living on Fungi.. Springer-Verlag, New York, 19-101.

Merckx VSFT, Kissling J, Hentrich H, Janssens SB, Mennes CB Specht CD, Smets EF (2013b). Phylogenetic relationships of the mycoheterotrophic genus Voyria and the implications for the biogeographic history of Gentianaceae. American Journal of Botany 100: 712-721. https://doi.org/10.3732/ajb.1200330

Merckx VSTF, Stöckel M, Fleischmann A, Bruns TD, Gebauer G (2010) $15 \mathrm{~N}$ and 13C natural abundance of two mycoheterotrophic and a putative partially mycoheterotrophic species associated with arbuscular mycorrhizal fungi. New Phytologist 188: 590-596. https://doi.org/10.1111/j.1469-8137.2010.03365.x

Silva Júnior, CHL, Anderson, LO, Cruz de Aragão, LEO, Rodrigues, BD (2018). Dinâmica das queimadas no Cerrado do Estado do Maranhão, Nordeste do Brasil. Revista do Departamento de Geografia 35: 1-14. https://doi.org/10.11606/rdg.v35i0.142407

SpeciesLink (2018) http://www.splink.org.br. Accessed on: 2018-8-2. Struwe L, Kadereit JW, Klackenberg J, Nilsson S, Thiv M, Von-hagen KB, Albert VA (2002) Systematics, character evolution, and biogeography of Gentianaceae, including a new tribal and subtribal classification. In: Struwe L, Albert VA (Eds) Gentianaceae, Systematics and Natural History. Cambridge University Press, Cambridge, 21-301.

Thiers B (2018) Index Herbariorum: a global directory of public herbaria and associated staff. New York Botanical Garden's Virtual Herbarium. https://sweetgum.nybg.org/ih/. Accessed on: 2018-3-2.

Tropicos (2018) Missouri Botanical Garden. http://www.tropicos.org/ Name/13801984. Accessed on: 2018-3-2. 